not comply with strict requirements of etymological studies. The author of the book comes up with imaginative ideas but, taking into consideration the unclarified nature of the historical events and the lack of dated presentation of (Proto-)Romance data, these ideas do not pass the test of reliability. In sum: the book does not prove that Latin and (Proto-)Romance loanwords would have been borrowed into Hungarian in the Proto-Hungarian period.

Keywords: Proto-Hungarian, putative Latin/Romance loanwords, methodological problems in research on early loanwords.

KISS JENÖ

ELTE Eötvös Loránd Tudományegyetem

\title{
Keresztnévből származó madárnevek és a rejtett hangutánzás
}

A személyneveket általában köznevekre szokás visszavezetni. Ellenkező irányban, a keresztnevek egy része a nyelvhasználat során közszóvá válhat. Megtörténhet a köznevesülés minden alaki változtatás nélkül (ebben az esetben a poliszémia egy esete jön létre), de kaphat a köznevesült keresztnév valamilyen toldalékot, esetleg összetett szó elő- vagy utótagjaként válhat köznévvé. Közszóként leggyakrabban valamilyen emberi jellegzetességet, tulajdonságot jelölnek, de előfordulnak állatok, növények, tárgyak neveként vagy egyéb jelentésben is. (A köznevesülésröl: HAJDÚ 2003: 71-82.) Az alábbiakban - némi kitekintés után - a magyarban, a nyelvjárásokban keresztnévből lett madárneveket mutatom be, különös tekintettel a rejtett hangutánzásra. Keresztnévnek madárnévvel való véletlen egybeesésére is hozok példát.

CLAUDE LÉVI-STRAUSS hívta fel a figyelmet arra, hogy a francia népnyelv a madaraknak fajuk szerint ad keresztnevet: a veréb (le moineau) Pierrot, a papagáj (le perroquet) Jacquot, a szarka (la pie) Margot, a pinty (le pinson) Guillaume, az ökörszem (le troglodyte) Bertrand vagy Robert, a vízi guvat (le râle d'eau) Gérardine, a kuvik (la chevêche) Claude, az uhu (le grand duc) Hubert, a holló (le corbeau) Colas, a hattyú (le cygne) Godard, s használhatók ilyen kifejezésekben: Il y a trois pierrots sur le balcon 'Három veréb van az erkélyen' (1962: 266). Hasonló kifejezésmód az angoloknál is előfordul, akik szintén keresztnevekkel kedveskednek némely madárnak, s így Jenny Wren az ökörszem, Jack Daw a csóka, Tom Tit a kékcinke, Robin Redbreast pedig a vörösbegy neve. Az angol parrot 'papagáj' valószínúleg a francia Perrot (régi és nyelvjárási 'Péterke', Pierre kicsinyítő képzővel, a köznyelvi Pierrot megfelelője) származéka, amely régebbi nyelvváltozatokban a házikedvencnek tartott madarakat jelölte. Az ugyancsak angol és említett jackdaw 'csóka' madárnév előtagja azonban nem egyszerüen keresztnév, hanem ,rejtetten (közvetve) hangutánzó”, a magyar hangutánzó csóka megfelelője, utótagja pedig germán elem, a német Dohle 'csóka' megfelelője. A magyar csóka hangutánzó eredetű ugyan, „de legvalószínübben valamely szláv nyelv hangutánzó szavát vettük át” (KISS 1984: 329).

LÉVI-STRAUSS idézett művében rámutatott, hogy a madaraknak (és egyéb állatoknak) adott keresztnevek azt tudatják, hogy az illető állat - legalábbis metaforikusan - az emberi társadalom, sőt akár a család része, s a keresztnevekből származó madárnevek rendszert képeznek (,nous conceivons le monde des oiseaux comme une société humaine métaphorique", 1962: 271). Azt magyarázva, hogy miért éppen a madarakat nevezik ke- 
resztnévvel a franciák, LÉVI-STRAUSS a következő jellemzést adta: a tipikus madár szabad, kicsinyeit családban neveli, fajtársaival kommunikál, mégpedig az artikulált nyelvet idéző madárhangon (1962: 271).

Ellentétes irányú névadást képviselnek, de a természetnek és a társadalomnak egy rendszerben való kezelését tanusítják a nőknek adott, virágnevekből származó keresztnevek (a franciáknál Rose, Violette, a magyarban Rózsa, Ibolya, vö. LÉVI-STRAUSS 1962: 270). A magyar szakirodalomban GOMBOCZ ZOLTÁN mutatott rá arra, hogy a magyarság egykori totemizmusa őrződött meg a török eredetü személynévanyagban (GOMBOCZ 1915; vö. PAIS 1975: 300-327). Olyan madárnevekből (különösen ragadozó madarak elnevezéseiből) lett személynevek is árulkodnak erről, mint Ákos, Alattyán, Bese, Karcsa, Kartal, Tiván, Torontál, Turul, Zongor (GOMBOCZ 1915: 8-17; PAIS 1975: 301-302).

A magyarban a gábor, gábormadár a sárgarigó neve volt (a gáborján 'tövisszúró gébics' is a Gábor szó fejleménye), mátyás, mátyásmadár egyes nyelvjárásokban 'szajkó', ágnesmadár a Felvidéken 'harkály' stb., de a franciához fogható megfelelések nincsenek. Ráadásul a magyarban e madárnevek jelentős része - így éppen a gábor és a mátyás - keresztnév mintáját mutatja, de hangutánzó eredetü. Hasonlóképpen hangutánzó eredetủ a népnyelvi vakvarjú, kvakvarjú 'bakcsó' elötagja, a bakcsó első szótagja (a -csó kicsinyítő képző, KISS 1984: 63). Így - elsősorban KISS JENÖ (1984) nyomán - néhány „rejtetten hangutánzó" madárnevet is említek.

Ezeknek a „rejtetten onomatopoétikus” madárneveknek a tanulmányozása a modern etnobiológiában is napirenden van. Hogy tankönyvpéldákat említsek, az amerikai angol madárnevek közül ebbe a típusba tartozik az egyik amerikai (ám Európában is elő-előkerülö) lilefaj (ékfarkú lile, Charadrius vociferus) kill-deer (szó szerint 'szarvasölö') elnevezése, egy amerikai kecskefejöfaj (Caprimulgus vociferus) whip-poor-will (szó szerint 'ostorozni a szegény akaratot') neve (HuNN-BROWN 2011: 321). Az ékfarkú lile kill-deer és a Caprimulgus vociferus whippoorwill ('üsd szegény Vilit!') nevét JAKABB OSZKÁR is említette (2012: 77, 101). Egy helyi uhufaj (Bubo virginianus) neve az etnobiológiában kitüntetett tzeltal majáknál tuh-kulum-pukuh, szó szerint 'az ördög büze', ám hangutánzó összetétel is egyben (HUNN-BROWN 2011: 321). Ugyancsak rejtetten hangutánzó a vadgerle angol turtle dove (szó szerint 'teknősbéka-galamb') összetetett elnevezésének előtagja (JAKABB 2012: 104; német megfelelőjének, a Turteltaube szónak az előtagja egyszerüen hangutánzó). A kortárs etnozoológia legnagyobb szaktekintélyének, a Magyarországon is megfordult EUGENE S. HuNN-nak egyenesen az a véleménye, hogy az az igazán jó madarász és nyelvész egyben, aki minél több „rejtett (indirekt, közvetett) onomatopoézist” regisztrál egy-egy madárelnevezés-rendszerben. KISS JENŐ monográfiája (1984) alighanem elnyeri tetszését. (A HUNN által is müvelt etnozoológiába bevezetés magyarul: BABAI-AVAR-ULICSNI 2016.)

Újabb vizsgálódásokban az derült ki, hogy absztrakt fonoszemantikai szempontok szerint, az adott szemantikai mezőben, morfofonológiai kritériumoknak megfelelve a magyarban a jó madárnév kritériumai a következők: ne alternáljon, legyen kétszótagos, tartalmazzon szibilánst és likvidát stb. (ABONDOLO 2007; KICSI 2015). Az alább említendő madárnevek közül a gábor, gábos, gyuszi, jános, lili, mátyás és pétör is közelít ehhez az ideálhoz, ami nem meglepö, mivel a magyar keresztnevek is gyakran kétszótagosak.

Rátérve a keresztnévből származó madárnevek felsorolására, a felvidéki Felbáron ágnesmadár 'harkály' (Szól az Ágnes-madár, esö lesz holnap, ÚMTsz. 1: 164; TAKÁCS 2001; FERCSIK-RAÁTZ 2009: 243). 
A gábos, gábor, gáborka-madár, gábormadár a 16-18. században talán a sárgarigó (vagy valamely gébics) neve volt (KISS 1984: 324). PÁPAI PÁRIZ FERENC és BOD PÉTER latin-magyar szótárában a latin Galbula megfelelői Gáborka, Gábor-madár (1767a: 263), a magyar-latin-német szótárban Gabos a madárnév (1767b: 106). Utóbb a gábor 'sárgarigó' jelentést magyarázták a latin galbula 'sárgarigó' alapján is (KISS 1984: 246).

A tövisszúró gébics népi elnevezései közt szerepel a gáborján, szarkagáborján, szarkagábrián (több alakváltozattal), az egymással szimmetrikus szarkagábor és gáborszarka összetételek, valamint a vasgáborján, vasfejü gáborján, vasfejü gobri, nagyfejü gábor, nagyfejü gáborján (KISS 1984: 246-7). KISS JENÖ 19. századi megfigyelésekre is alapozott véleménye szerint a tövisszúró gébics hangja alapján kapta a gábor nevet, $\mathrm{s}$ az alább említendő györgydiák nevének előtagja is hangutánzással magyarázható (1984: 246). A nagy örgébics nyelvjárási elnevezései között is szerepel a gábor, gáborka, gábos, gáborján, nagyfejü gáborján (KISS 1984: 251). A 19. századi nyelvjárásokban nagyfejü gábor 'banka' (Bácska) vagy 'tövisszúró gébics' (MTsz. 1: 664), a vasfejü gábor 'tövisszúró gébics' (MTsz. 2: 928). A Magyar Nyelvjárások Atlaszában, a 20. század közepe e nagyméretü, tájszókat is felmérő vállalkozásában a tövisszúró gébicsnek kivételesen sok, 67 megnevezése (tautonimája, nyelvföldrajzi szinonimája) fordul elö, melyek közül a Gábor szóra vezethető vissza a gábics, gáborincs, gáborján, gáborszarka, szarkagábor, szarkagáborján, vasfejü gábor, vasfejü gáborján, vasgáborján (MNyA. 627; KISS-BATÓ 2012: 145-146). A 20. századi nyelvjárásokban gáborgyán, gáborszarka, nagyfejü-gábor, nagyfejü-gáborján, nagyfejü-szarkagáborján, szarkagábor, szarkagáborján, vasfejügábor, vasfejü-gáborján, vasgáborján mind 'tövisszúró gébics', ritkábban 'őrgébics' (ÚMTsz.). A Felsö-Szigetközben szarkagábrián, szarkagábor 'őrgébics' (KovÁcs 1987: 85). Magának a több változattal (gebecs, gebics, gebös, gibics, gibíz, MTsz. 1: 684; ÚMTsz. 2: 620; KISS-BATÓ 2012: 146) a nyelvjárásokban is meglevő gébics szónak az etimológiáját is szokás a Gábor valamely változatára (Gáborján vagy Gábos) visszavezetni (KISS 1984: 245; FERCSIK-RAÁTZ 2009: 105; JAKABB 2012: 159). A gábor szónak egyébként a Székelyföldön volt 'farkas' jelentése is (MTsz. 1: 664).

A gazsi-gazsi mondatszó többször ismételve a liba hívogatására szolgál Hódmezővásárhelyen (ÚMTsz. 2: 619). A gazsi azonban nem állatnév, csak a hívogatóban fordul elő.

A gegö 'tövisszúró gébics' nyilvánvalóan a Gergely és Gergő ritkább Gegő becézésére vezethető vissza, ám egyben hangutánzó eredetű (Felvidék, ÚMTsz. 2: 622; KISS 1984: 248; KISS-BATÓ 2012: 146). Említésre méltó, hogy a gólya egyik - talán hangutánzó eredetű - nyelvjárási megnevezése a palatális gegő veláris párja, a gagó (elsősorban Bereg és vidéke, de még Székelyföld és Szlavónia is, MTsz. 1: 666; ÚMTsz. 2: 581; KISS 1984: 70; KISS-BATÓ 2012: 61).

A gyöngyvér madárnév a régi magyarban és elsősorban az Alföldön a nagy liliket jelölte, de más madarakat is (KISS 1984: 68, 78, 172; ÚMTsz. 2: 761). PÁPAI PÁRIZ FERENC és BOD PÉTER magyar-latin-német szótárában a Gyöngyvér latinul Anser silvaticus, németül eine wilde Gans (1767b: 115). A Gyöngyvér női keresztnév Arany János leleménye (FERCSIK-RAÁTZ 2009: 296). A Gyöngyvér és Gyöngyi becézése Gyöngyös; a gyöngyös pedig a gyöngytyúk népies elnevezése (ÚMTsz. 2: 760). Nem keresztnévből lett tehát se a gyöngyvér, se a gyöngyös.

A györgydiák 'tövisszúró gébics' összetétel előtagja valószínüleg hangutánzó eredetű (Heves, MTsz. 1: 759; KISS 1984: 246; TAKÁCS 2001). A György helyi becenevei, 
a gyura (Nagykanizsa) és a gyuri (Szentgál) egyaránt 'kakas' (ÚMTsz. 2: 765, 766), míg a gyurka 'rosszul kiherélt kakas' (Veszprém megye, ÚMTsz. 2: 766; TAKÁCS 2001; FERCSIK-RAÁTZ 2009: 115). A gyurgyalag hangadását gyakran adják vissza a gyurr-gyurr mondatszóval (például JAKABB 2012: 114), ám a gyurgyalag elnevezés közvetlenül hangutánzó (KISS 1984: 214). E madárfaj egyetlen feljegyzett, a György szót becéző elnevezése a gyura a Felső-Szigetközben, ahol a gyúgyallag, gyógyalag, gyúrgyala és méhész társneve (KovÁcs 1987: 79).

A gyuszi 'veréb' tréfás névadással jött létre (KISS 1984: 317; KISS-BATÓ 2012: 154).

A jános Komáromban 'pulykakakas' (ÚMTsz. 2: 1133). A 'kakas' jelentés kapcsán érdemes megjegyezni, hogy a baromfiak közül legfeljebb a kakasnak, gácsérnak, gúnárnak, esetleg kotlósnak szokás nevet adni.

Két török előtaggal magyarázott madárnév is népetimológiával, a Károly névvel kapott névváltozatot. PÁPAI PÁRIZ FERENC és BOD PÉTER a Karoly szónak még egyaránt megadta a latin 'Nisus' és 'Carolus', illetve 'Sperber' és 'Karl' jelentést (1767b: 162). Ugyancsak régi (1793) adat a Károlymadár 'karvaly' (KISS 1984: 108). Magának a karvaly szónak vannak karoly, karoj alakváltozatai egyes nyelvjárásokban (ÚMTsz. 3: 126). Ráadásul a karvaly szónak van kar- előtaggal, 'karon hordott madár' jelentéssel, solymászathoz kapcsolódva magyarázott - nehezen elfogadható - etimológiája is (JAKABB 2012: 63). Maga a Károly keresztnév is a karvaly szó alakváltozatai és a Károly személynév, valamint a latin Carolus és német Karl nevek egybeeséséből származtatható (FERCSIKRAÁTZ 2009: 147). A károlykatonája a kárókatona (kormorán) népetimológiás alakja (Kiskunság, ÚMTsz. 3: 121; korábban: Károl-katonája, 1793). E kifejezés érdekessége, hogy talán maga a kárókatona szó is valamely qara 'fekete' előtagú török madárnévböl keletkezett a katona népetimológiás beleértésével. A kiskunsági kifejezés pedig talán a madár színének és III. Károly katonái ruhaszínének hasonlóságán alapulhat, további népetimológiával (KISS 1984: 58; TAKÁCS 2001: 162; FERCSIK-RAÁTZ 2009: 149). Állítólag volt olyan szájhagyomány is, mely szerint a török nevezte el Mátyás király idejében a madarat kara-katoná-nak, sötét tolla, trombitára emlékeztető hangja alapján, a fekete sereget gúnyolva (JAKABB 2012: 183).

Bars vármegyében kata 'varjú' volt (MTsz. 1: 1069; ÚMTsz. 3: 143; TAKÁCs 2001), a nagy sirályok egyik neve pedig a Balatonnál Kata lúdja (KISS 1984: 182). Tunyogmatolcson kata, kata többször ismételve a kotlóstyúk hívására szolgált (ÚMTsz. 3: 144). A butykáskató (Szilágy vármegye) és butykóskató (Dombóvár) 'búbos pacsirta' volt (MTsz. 1: 203; ÚMTsz. 1: 644; KISS 1984: 233).

A lidike, lili, lilimadár Szeged környékén 'vöröslábú (vagy: piroslábú) cankó', s e neveit tavaszi trillázó füttyéröl (dlidl-dlidl-dlidl) kapta (ÚMTsz. 3: 862, 864, 865; KISS 1984: 161). A nyelvjárásokban a lili, lili-lili és lilike, lili, lili hangsorok kacsahívogatásra szolgálnak (ÚMTsz. 3: 864-865). A nyelvjárási és gyermeknyelvi lili és lilike 'kacsa', Makón lilike 'kisliba' (ÚMTsz. 3: 864-865). A lilik a Charadrius fajok népi neve volt (MTsz. 1: 1340), s a lili és lilik az Alföldön az Anser albifrons nevü lúdfajt is jelölte (MÉSZÖLY 1929). Ide tartozik két hangutánzó eredetü szaknyelvi madárnév, a lile és a lilik. A lilik két Magyarországon átvonuló lúdfaj (Anser albifrons, nagy lilik és Anser erythropus, kis lilik) nevében fordul elő (KISS 1984: 77-78; JAKABB 2012: 38-39); a lile a Charadrius és Pluvialis fajok nemi (genus) neve (KISS 1984: 147-150; JAKABB 2012: 76-78). MÉSZÖLY GEDEON szerint „a lilik szó a hangutánzó lili szó egyes számúnak értett többes számú alakja” (1929: 295). 
A lóri papagájfajok elnevezése, végső soron maláj eredetü szó, amely angol (lory) közvetítéssel terjedt el világszerte, s a magyarban is 1801-től adatolható (KISS 1985: 33). A Loránd és Lóránt keresztneveket becéző Lóri névvel való egybeesése a véletlen müve. A Lóri (akárcsak a Gyuri stb.) a díszmadártartók körében előszeretettel választott papagájnév. Ezek a házikedvenceknek adott keresztnevek mintegy családtaggá minősítik az illető madarat.

A lukácsmadár 'vetési (fekete) varjú' (Velem, Vas megye, KISS 1984: 332; TAKÁCS 2001; KISS-BATÓ 2012: 53).

Gyerőmonostoron (egykor Kolozs vármegye) a gyermekek ha harkályt láttak ezt mondogatták: „Mártonka, Mártonka, / Gyere lakodalomba! / Adunk neked virágot, / Hozzál nekünk kalácsot!" Ezzel párhuzamosan a harkály egyik német neve is Martinsvogel 'Márton madara' volt (WLISLOCKINÉ 1892: 52-53). Itt tehát a Mártonka a madár megszólítása ugyan, de csak a hozzá kapcsolódó, neki szóló mondókában fordul elő. Az angolban a Martin 'Márton' névvel egyezően egyes fecskefajok neve - a swallow mellett - martin (JAKABB 2012: 123-124); a franciában ugyancsak a Martin névre vezethetők vissza a martin-chasseur 'vadász Márton', martinet, martin-pêcheur 'halász Márton', martin rose 'rózsaszín Márton' madárelnevezések (DAUZAT 1938: 461).

A butamáté a Sóvidéken 'hantmadár' és 'búbosbanka' (GuB 1996: 67, 73). A máté a Székelyföldön egykor 'medve' (MTsz. 1: 1413). A búbosbanka messzire hallatszó pupu-pu vagy up-up-up háromtagú, tompa, egyhangú hangadása (JAKABB 2012: 115) magyarázhatja a buta- előtagot. Annál is inkább, mert például e madár latin (upupa), angol (hoopoe), francia (huppe), német (Hopf, Wiedehopf), román (pupăză) és orosz (udod és potatujka) neve is hangutánzó. Végső soron a búbosbanka összetett, szaknyelvi madárnév mindkét tagját rejtetten hangutánzónak lehet minősíteni: a búbos a madár tollbóbitájára utal, a banka 'bamba, buta' (KISS 1984: 219). A búbosbanka kínai és mongol neveit HENRY SERRUYS tekintette át, s gyüjtéséből kiderül például, hogy egyik régi, valamelyest rejtve hangutánzó kínai neve - a kakukkéval osztozva - bu-gu (ejtve: $p u-k u$ ), szó szerint, legalábbis leírva 'bejelenteni az aratást' (1977: 110), továbbá egyik belső-mongóliai kínai neve, a guang-gun (ejtve: kuang-kun) szintén rejtett hangutánzást képvisel, tulajdonképpeni jelentése 'puszta bot, csak bot; gazember, betyár; agglegény' (1977: 111). A bu-gu a kínaiban a kakukk neveként rögzült. A mai mongol övőlzsin 'búbosbanka' klasszikus mongol megfelelői az ebugelji, öbügelji, s kapcsolódnak az övő 'nagyapa, apó', a klaszszikusban ebuge szóhoz. A kínai monoszillabikus nyelv, amely erőteljesen a diszillabikus jelleg felé tart, s madárelnevezés-rendszere gazdag „rejtett hangutánzásban”.

A mátyás (Heves megye, Erdély, MTsz. 1: 1415; több más vidéken is, ÚMTsz. 3: 1022), mátyásmadár, mátyásszajkó, matyi, matyimadár mind 'szajkó' (KISS 1984: 326; TAKÁCS 2001; JAKABB 2012: 163). E madárfaj a keresztnévvel hangutánzó nevet kapott. Ugyancsak 'szajkó' jelentésű a kékmátyás (Nyírcsászári, ÚMTsz. 3: 174). A vajdasági diáknyelvben matyó 'veréb' (TAKÁCS 2001: 160), a matyi szónak pedig van 'rosszul ivartalanított kakas' jelentése is (Szeged, ÚMTsz. 3: 1022; TAKÁcS 2001: 160). KISS JENÖ monográfiájához képest újabb közlések szerint a Felső-Szigetközben és a Sóvidéken egyaránt mátyás, mátyásmadár, matyi 'szajkó' (KovÁcs 1987: 82; GuB 1996: 65), külön a Sóvidéken a havasimátyás és a pettyesmátyás 'fenyőszajkó' (GuB 1996: 67).

A Vas megyei Molnaszecsődön a „Cici Pál, mit csinál? Tudja Pál, mit használ” mondókában tulajdonképpen belehallás utánozza a széncinke szavát, s a rábaközi Mihályiban 
csicsipál 'széncinke' (KISS 1984: 293). A széncinke hangját a magyar hagyományban különösen sok belehallás adja vissza (RÁcz 1992: 39-43). Keresztnevet tartalmazó belehallás a csíz szavára a Duli-duli-Dezső!, a stiglicére (tengelicére) a Cipity, Lörinc, cipity Lörinc! (RÁCZ 1992: 44). Az ugyancsak rábaközi pálimadár 'nagy póling' páli eleme a hangutánzó póli 'nagy póling' népetimológiás változata, egy rábaközi falu, Páli neve hatására is (KISS 1984: 166). Ez a Páli helynév a Pál keresztnév birtoklást kifejező - $i$ képzős származéka, tulajdonképpeni jelentése 'Pálé'.

A pétör (a péter helyi alakváltozata) a Szeged vidéki, tápéi galambászok nyelvhasználatában csirkéket, galambokat pusztító 'kánya, vércse', s azért kapta ezt a nevet, hogy igaz nevének kimondásával nehogy odaidézzék („odaigézzék”, BÁLINT 1981: 9; HAJDÚ 2003: 80; ÚMTsz. 4: 459; TAKÁCS 2001). A halászpéter általánosan 'búvármadár; halászmadár', külön-külön jelölheti az 'ezüstsirály' és a 'jégmadár' fajokat (Somogy, Keszthely, ÚMTsz. 2: 818; KISS 1984: 182, 214). A kispéter vagy kispétergalamb Gútán 'olyan vadgalambfajta, melynek nyakán két fehér örv van' (ÚMTsz. 3: 380; FERCSIKRAÁTZ 2009: 200).

Valamennyi említett, keresztnévből származó magyar madárnév nyelvjárási szó, közülük talán csak a gáborján, a mátyás és a mátyásmadár valamelyest köznyelvi. A köznyelvet is befolyásoló tudományos madárnévrendszer kidolgozásakor már helytelennek számított a madarakat az emberi társadalomhoz közelíteni, s kerülni illett a keresztnévmadárnév poliszémiát. (A magyar tudományos madárnévrendszer standardizációjáról: KISS 2010.) A keresztnévből származó nyelvjárási madárneveket tehát lehet egy archaikus gondolkodásmód (a madár a társadalom tagja, a madár családtag) képviselőinek tekinteni.

A madárhangnak emberi nyelvre átfordított változatai a következők: közönséges hangutánzó mondatszók (csip-csirip, gyurr-gyurr), a madár hangadását jelölő hangutánzó igék (csiripel, huhog, krúgat), belehallások (már meglevő, értelmes szavakra való fordítások, a széncinege hangjába: nyitni-kék, tüz-kö, künn-csücsü), hangutánzó madárnevek (kakukk, pitypalatty, uhu), madaraknak adott hangutánzó tulajdonnevek (papagájnak keresztnevek is: Lóri, Gyuri stb.). A belehallásról szóló monográfiájában RÁCZ ENDRE a harangok szavát, a vonat, a kerekek zakatolását, a házi- és vadállatok, tücskök, békák beszédét, a madarak énekét elemezte (1992). A közönséges hangutánzó mondatszók és a belehallások viszonyának analógiája a közvetlenül (direkt) hangutánzó és a rejtetten (közvetve) hangutánzó madárnevek viszonya. A keresztnévvel hangutánzó madárnevek (a fenti példákban: butamáté, csicsipál, gábor és gábormadár sok változattal, gegö, györgydiák, lidike, lili, lilimadár, mátyás, mátyásmadár, matyi) a „,rejtett onomatopoézist” képviselik. Ezek a madárnevek úgy jöttek létre, hogy a madárhanghoz valamennyire hasonlító keresztnév lett madárnévvé vagy annak részévé is. Mindenesetre meglehetősen önkényesen dőlt el, hogy 1. mely madár kapott keresztnévből származó nevet és 2. mely madár kapott „,rejtetten hangutánzó” nevet.

A „rejtett hangutánzás” tekinthető a népetimológia egy különleges esetének is, amely során a beszélő a számára különös madárhangot (és jelen esetben nem az idegen szót) értelmessé, átlátható szerkezetüvé teszi, és madárelnevezésként vagy annak részeként használja.

A rejtett (indirekt) hangutánzással jelölt madarak elnevezései más nyelvekben gyakran hangutánzók. Ilyen példa volt a búbos banka, további példa az angol jay 'szajkó' (hangutánzó, ófrancia jövevényszó) és shrike 'gébics'. A szajkó egyébként a személy- 
névvel való hangutánzás régi példáját kínálja: francia neve, a geai (a 12. században: gai) vagy közvetlenül hangutánzó, vagy a „,rejtetten hangutánzó’ latin gaius madárnév (5. század, Polemius Silvius) folytatása, s a latin madárnév a Gaius személynévből származik (DAUZAT 1938: 357).

Kulcsszók: magyar népi madárnevek, hangutánzó madárnevek, keresztnévből származó állatnevek, hangutánzás, belehallás, népetimológia.

\section{Hivatkozott irodalom}

ABondolo, Daniel 2007. Phonosemantic subsets in the lexicon: Hungarian avian nomenclature and l'arbitraire du signe. Central Europe 5/1: 3-22.

BABAi DÉNIEL - AVAR ÁKOS - ULICSNI VIKTOR 2016. „Veszélyes a varas béka, rossz fajzat!” avagy mit kutat az etnozoológia? Kovász 20: 3-29.

BÁLINT SÁNDOR 1981. A hagyomány szolgálatában. Összegyüjtött dolgozatok. Magvető Könyvkiadó, Budapest.

DAUZAT, AlBert 1938. Dictionnaire étymologique de la langue française. Larousse, Paris.

FERCSIK ERZSÉBET - RAÁTZ JUDIT 2009. Keresztnevek enciklopédiája. A leggyakoribb nöi és férfinevek. Tinta Könyvkiadó, Budapest.

GOMBOCZ ZoLTÁN 1915. Árpádkori török személyneveink. A Magyar Nyelvtudományi Társaság Kiadványai 16. Magyar Nyelvtudományi Társaság, Budapest.

GuB JenŐ 1996. Erdő-mezö állatai a Sóvidéken. Firtos Mủvelődési Egylet, Korond.

HaJdú MiHÁLY 2003. Általános és magyar névtan. Személynevek. Osiris Kiadó, Budapest.

Hunn, Eugene S. - Cecil H. Brown 2011. Linguistic Ethnobiology. In: E. N. Anderson et al. eds., Ethnobiology. John Wiley \& Sons, Hoboken (New Jersey). 319-333.

JAKABB OsZKÁR 2012. Madárnévkalauz. A Kárpát-medence madarainak névkalauza. Tinta Könyvkiadó, Budapest.

KICSI SÁNDOR ANDRÁS 2015. Madárnévség. Ezredvég 25/5: 93-95.

KISS GÁBOR - BATÓ MARGIT 2012. Tájszavak. A magyar nyelvjárások atlaszának szavai, szóalakjai. Tinta Könyvkiadó, Budapest.

KISS JENŐ 1984. Magyar madárnevek. Az európai madarak elnevezései. Akadémiai kiadó, Budapest.

KISS JENŐ 1985. A pingvintől a kolibriig. Egzotikus madarak magyar nevei. Nyelvtudományi Értekezések 120. Akadémiai kiadó, Budapest.

KISS JENŐ 2010. A szaknyelvi standardizáció történetének néhány kérdéséhez. In: BÁRDOSI VILMOS szerk., Világkép a nyelvben és a nyelvhasználatban. Tinta Könyvkiadó, Budapest. 147-154.

KOVÁCS ANTAL 1987. „Járok-kelek gyöngyharmaton...” Növény- és állatnevek a Felsö-Szigetköz tájnyelvében. Mosonmagyaróvári Helytörténeti Füzetek 6. Hazafias Népfront Városi Bizottsága, Mosonmagyaróvár.

LÉvi-STRauss, Claude 1962. La Pensée sauvage. Plon, Paris.

MÉSZÖLY GEDEON 1929. Urál-altáji szó-e a lili vagy lilik madárnév? Népünk és Nyelvünk 1: 292295.

MTsz. = SZINNYEI JÓZSEF, Magyar tájszótár 1-2. Hornyánszky, Budapest, 1893-1901.

PAIS DEZSÖ 1975. A magyar ősvallás nyelvi emlékeiböl. Akadémiai Kiadó, Budapest.

PÁPAi PÁRIz FERENC - BOD PÉTER 1767a. Dictionarium Latino-Hungaricum. Sárdi Sámuel, Cibinium (Nagyszeben).

PÁPAI PÁRIZ FERENC - BOD PÉTER 1767b. Dictionarium Hungarico-Latino-Germanicum. Sárdi Sámuel, Cibinium (Nagyszeben). 
RÁCZ ENDRE 1992. A belehallás jelenségéröl. Nyelvtudományi Értekezések 134. Akadémiai Kiadó, Budapest.

SERRUYS, HENRY 1977. A note on the names of the hoopoe in Chinese and Mongol. The CanadaMongolia Review. La Revue Canada-Mongolie 3/2: 110-117.

TAKÁCS JUDIT 2001. Keresztnévből származó állatnevek. Magyar Nyelvjárások 39: 159-164.

ÚMTsz. = Új magyar tájszótár 1-5. Főszerk. B. LÖRINCZY ÉVA. Akadémiai Kiadó, Budapest, 19792010.

WLISLOCKI HENRIKNÉ 1892. Jósló állatok a kalotaszegi néphitben. Ethnographia 3/2-3: 47-55.

\section{Bird names based on people's first names and covert onomatopoeia}

Some Hungarian popular bird names come from people's first names, albeit none of them have become official names of the bird species concerned. Many of them are also onomatopoetic in addition to being based on first names; thus such bird names exhibit "covert onomatopoeia". Examples include butamáté (<Máté) 'hoopoe', csicsipál (<Pál) 'great tit', gábor and gábormadár with many other variants (< Gábor) 'shrike', gegö (< Gergó), györgydiák (< György), both: 'butcher bird', lidike (< Lidia), lili, lilimadár $(<$ Lili), all three: 'redshank', mátyás, mátyásmadár, matyi $(<$ Mátyás), all three: 'jay'. These bird names came into being such that a human first name that more or less resembled the given bird's song was turned into (part of) a bird name. It was rather arbitrary (i) which birds received first name based names and (ii) which birds received names with "covert onomatopoeia". In modern ethnobiology, American bird names like killdeer and whip-poor-will are similarly instances of "covert onomatopoeia".

Keywords: Hungarian popular bird names, onomatopoetic bird names, bird names based on people's first names, onomatopoeia, reanalysis, folk etymology.

KICSI SÁNDOR ANDRÁS

\section{„Tekintsétek az égi mennyei repöső madarakat..."}

\section{A menny és ég szavak ómagyar bibliafordításainkban*}

1. Korai bibliafordításaink jelentősége és kérdései. A korai magyar bibliafordítások, a magyar nyelvü (fordítás)irodalom első összefüggő emlékei több szempontból egyedülállóak és egyedi kutatási kérdéseket vetnek fel. A korábbi, kisebb szövegemlékekhez képest ezek az első, már hosszabb, összefüggő szövegek, amelyekben a magyar nyelv, különösen is az egyházi nyelv szó- és kifejezéskészletének alakulását, sokszor megszületését kísérhetjük figyelemmel. KÁROLY SÁNDOR megfogalmazásában a szövegekben „az a harc tükröződik, melyet a fordítóknak a latinnal kellett megvívniok. Mivel akkor még nem volt egységes irodalmi köznyelv, nyelvjárási, tájnyelvi sajátságok keverednek benne írott nyelvi újításokkal és latinizmusokkal" (KÁROLY 1972: 88). Emellett érdemes arra is felhívni a figyelmet, hogy egy bizonyos élőbeszédben öröklődő és kikristályosodó szöveghagyománnyal is számolhatunk (erröl részletesen 1. TARNAI 1981), mely olykor

* A tanulmány az Emberi Erőforrások Minisztériuma Új Nemzeti Kiválóság Programjának támogatásával készült. 